\title{
Web-based corporate social responsibility information disclosure by Malawian commercial banks
}

\author{
Andrew Munthopa Lipunga ${ }^{1}$ \\ ${ }^{I}$ Department of Accountancy, University of Malawi-The Polytechnic, Malawi
}

\begin{abstract}
The purpose of the study was to evaluate the level of online CSR disclosure by banks in Malawi and make a comparative analysis with the level of CSR disclosure in the annual reports. Furthermore, the study examined the influence of the listing status on CSR disclosure. CSR score was used in measuring the level of CSR disclosure and regression analysis in examining the influence of listing status. The results indicated low level of CSR disclosure by the sampled banks in Malawi. Relatively lower level was found for online reporting (0.14) compared to (0.4) for CSR reporting in annual reports, besides, significant difference was found between the two. The study also found that CSR disclosures were generally shallow, largely pictorial and unsystematic in both cases. Finally, study revealed that listing status have insignificant influence on the level of CSR disclosure. The results indicate that more need to be done to enhance CSR reporting among the banks in Malawi. The study recommends incorporation of the minimum CSR guidelines in the current corporate governance guidelines for the Malawian banks and monitoring compliance by the regulatory authorities to ensure comprehensiveness of the disclosures.
\end{abstract}

Keywords: Annual reports, corporate social responsibility (CSR), online CSR reporting, Malawi

\section{Introduction}

The goal of contemporary companies is to maximise the value of shareholders and simultaneously satisfy the expectations of other stakeholders (value of stakeholders) [1]. This is the case because companies are increasingly expected to behave in a socially responsible manner and embrace the concept of managing resources for the well-being of current and future generations as they are maximising shareholder wealth [2]. This social concern has given birth to the concept called corporate social responsibility (CSR) [3]. CSR is considered not simply as a thing for large corporations or listed companies; but on the contrary it is generally about responsible business practices or in other words "business responsibility" [4]. According to Masud (2011) [5]:

"CSR can be viewed as a comprehensive set of policies, practices, and programs that are integrated into business operations, supply chains, and decision making processes throughout the company and include responsibilities for current and past actions as well as adequate attention to future impacts."

CSR is now a matter of survival. Business organizations are required to prove of their accountability to the society associated with the profit maximisation motive in order to preserve the prolonged existence of the corporate image [3]. Thus the companies are obliged to provide information to the public on how they are doing in relation to their social responsibility. This has as a result given birth to CSR reporting. CSR reporting is a means by which companies reflect the social and environmental aspects upon which companies' activities may have an impact i.e. employee related issues, community involvement, environmental concerns, other ethical issues, etc [6].

CSR reporting involves disclosure of information about companies' interactions with society thus it is also called social responsibility disclosure [6]. The disclosures are supposed to include both positive and negative impacts of business operations on labour standards, the environment, economic development, and human rights [7]. With the increasing importance of CSR, corporations are forced to rethink the part played by CSR reporting in communicating how best they balance the needs of meeting both shareholder value maximisation and the wider requirements of other stakeholders [8]. The goal of CSR reporting, is to generate new and better information on the performance of firms, to support more informed decision-making by key stakeholders, and ultimately to create new incentives for companies to reduce adverse impacts of their activities [7]. It is acknowledged that providing fuller information on the environmental, social, and economic impacts of business activities allows stakeholders to make more informed decisions about individual and collective development alternatives [7].

CSR reporting is seen as a linchpin of efforts to evaluate the impacts of corporate activities, to identify best practices, and to promote continuous improvements in firm performance [7]. According to O'Rourke (2004) [7]: 
"The primary drivers for CSR reporting have come from a range of social actors and interests: public demands for a "right-to-know" about the impacts of corporate activities, consumer concerns about environmental and social impacts of specific products, government attempts to use disclosure as a strategy of regulation, and financial institution demands for fuller disclosure of nonfinancial risks."

In the current era CSR reporting has far-reaching implications. On the entire economy, adequate corporate social responsibility disclosure has important implications on the credibility of the capital markets [9] as a result improving the flow of capital. On the company level, CSR disclosure has become a strategy for creating and responding to market incentives for improved performance, and a means for mitigating risks of market sanction [7]. On the wider society, disclosure of information on externalities increases information available to impacted parties, which can support negotiations over the fair distribution of those impacts [7]. Thus, due to its pervasiveness communication of CSR activities should be directed not only to customers, business partners, investors, but to company's employees, the local community and the general public as well [10].

The current challenge of organizations is therefore to disclose information in a cost-efficient fashion while maximising its reach [11]. Cormier et al. (2010) [11] recognised that typically most organizations disclose non-financial information through traditional media vehicles (e.g., annual report) or intermediaries (e.g., press releases to be picked up by the media). However, development of Internet has opened up a new and faster however cheap way of communication and companies are rethinking on their communication strategies. Cormier et al. (2010) [11] stated that:

"the advent of the World Wide Web (Web) brings firms to reconsider their disclosure strategies as it allows for direct communications with - current and potential-stockholders, irrespective of their location and without the need for intermediaries. Moreover, there is essentially no marginal distribution cost if additional information is conveyed. Such a context implies that the stewardship relation between a firm's management and its stockholders becomes more direct, dynamic and interactive.

Communication through the web is particularly crucial in this era of globalisation and liberalisation. According to Lepczynski (2003) [12] globalisation and liberalisation of capital flows had resulted in the growth of competition in the capital acquisition market. Companies and countries are increasingly being evaluated not only for their economic performance, but also for their social, environmental, labour, and human rights policies and impacts [7]. Lepczynski (2003) [12] also recognised that the freedom of capital migration is limited mainly by the reputation and liquidity of markets and institutions which is evaluated by social, ethical and environmental criteria more and more often. Besides, Penczar (2003) [1] noted that with globalisation of financial markets companies will meet investors that are more aware of Corporate Social Responsibility and consumers that invest and co-operate better with companies supporting environmental and social development. In order to be relevant in this globalised economy, CSR reporting on the Internet is a necessity as it enables companies to transmit information quickly [7] widely and at low cost.

Thus at present Internet has become an important medium through which companies can disclose information of different natures including CSR disclosures [6]. Internet is now a tool for organizations to create consistency between their internal and external images [13]. According to Wanderley et al. (2008) [14] corporate websites are providing an official perspective regarding CSR within the corporation for all its stakeholders. Thus, using the corporate websites deduction can be made of how a company wishes to be perceived regarding their belief, work and behaviour both in the marketplace and in society [13].

The benefits of CSR reporting through the Internet are enormous and undoubted [15]. Internet allows companies to publicise more information less expensively, in timely fashion and interactively than ever before [14]; [15]; [6]. Wanderley et al. (2008) [14] explained that unlike traditional media (newspapers, magazines, billboards, television and radio), the Internet allows the company to publicise detailed, up-to-date information. Moreover, the information remains permanently available on the web, allowing the Internet user to choose which subjects he/she wants to access and as often as he/she wishes. Furthermore, Branco and Rodrigues (2006) [6] recognise that one of the more interesting features of the internet is that it allows companies to provide information targeted to different stakeholders and to obtain feedback from them.

The study was aimed at evaluating level of online CSR reporting by commercial banks in Malawi and making a comparative analysis with CSR reporting in the annual reports. The study also examined the influence of listing status on the level of CSR reporting. In Malawi CSR reporting is generally voluntary except for the banking sector. Banks are required by the corporate governance guidelines for the banks, issued by the Reserve Bank of Malawi to report on their corporate social responsibility and activities [16]. The guidelines only require the CSR disclosures to be made in the annual reports [16], thus Internet is a voluntary vehicle. However considering the increasing importance online CSR reporting expectation of the study was that level of online reporting should not be significantly different to the level of CSR reporting in the annual reports. The rest of the paper is structured as follows. The second section reviews the prior studies followed by section three which 
discusses the research methodology. Section four presents the results of the study and the resultant discussion and finally the paper finishes with some concluding remarks.

\subsection{Prior studies}

\section{Literature Review}

Corporate social responsibility (CSR) has become a much-discussed subject in the business world [14]. It is a flourishing and evolving concept that attempts to recognise the fact that business organizations are primarily governed by profit maximization imperative coupled with moral and ethical concern [3]; [17]. It is known by different names such as Corporate Responsibility, Corporate Citizenship, Corporate Philanthropy, Responsible Business etc however despite different names, the concept is generally geared to promoting social justice to society and environment [17]. According to CAMAC (2006) [4] CSR means not just fulfilling legal obligations, but voluntarily adopting business practices that go beyond legal and regulatory compliance by integrating business activities with a balanced response regarding wider considerations for the environment, human and social capital. Thus Masud (2011) [5] recognises that the role of business worldwide and particularly in the developed economies has evolved over from classical 'profit maximising' approach to a social responsibly approach, where businesses are not only responsible to its stockholders but also to all of its stakeholders in a broader inclusive sense.

Hossain and Reaz (2007) [18] showed that financial institutions provide voluntary corporate information including social information as part of their social responsibility and corporate citizenship. In providing the CSR information, Arnold (2009) [8] indicated that companies use both paper-based and electronic-based (website) means. Thus a number of studies have been carried out in relating to CSR reporting by commercial banks in their annual reports and online. In Malawi, Lipunga (2013) [19] explored CSR reporting practices in annual reports of commercial banks. Using content analysis the study found that all the sampled banks (100\%) made some sort of CSR disclosures however the overall disclosure level was low (0.3). Similar study was conducted by Tandanu and Wibowo (2008) [20] in Indonesia, however that study went further to examined the characteristics of the disclosing banks. Examination was made on social responsibility information disclosures on 2004-2006 annual reports using content analysis. It was found that, banks with higher total assets and net income as well as that were state-owned disclose more than banks with lower total assets, lower net income, and private-owned.

Furthermore, Hossain and Reaz (2007) [18] empirically investigated of the extent of voluntary disclosures which included CSR of 38 listed banking companies in India. Their findings also indicated that size and assets in-place were significant factors while other variables such as age, diversification, board composition, multiple exchange listing and complexity of business were insignificant in explaining the level of disclosure. Kousa (2011) [21] also indicated existence of a linear relationship between a company's size and the extent of its CSR reporting. On the other hand Cheung and Mak (2010) [22] suggested no definitive relationship exists, neither positive nor negative, between CSR disclosure and financial performance in commercial banks. In Indonesia, Kurniawan and Wibowo (n.d) [23] analysed the relationship between conservatism and CSR disclosure in 21 Indonesian banks that went public in 2003-2007. The analysis revealed no clear evidence to support the relationship between conservatism and the Indonesian banks' CSR reporting. Furthermore the findings suggested that generally CSR disclosure practices in Indonesian banks were driven by government regulation. The research found no any internal motive of the sample banks in disclosing their CSR activities voluntarily.

In relation to online CSR reporting, researchers have also endeavoured to study it both in relation to the banking sector and other sectors. Wanderley et al. (2008) [14] pointed out that corporate websites are providing an official perspective regarding CSR within the corporation for all its stakeholders. Tagesson et al. (2009) [24] recognised Internet as one important channel. Guimarães-Costa and Pina e Cunha (2008) [13] applied the image of a Roman atrium to disclosure of CSR activities on company websites, through an examination of the website content of 19 large companies operating in Portugal. Their analysis revealed that online CSR discourse targets stakeholders. They concluded that comparison with Roman atria can be made to the extent that (a) websites allow companies to suggest positive images about themselves, (b) their openness forces companies to adopt bifocal messages where the target does not always coincide with the message's subject and (c) their visibility and accessibility induce companies to take a position on external events and to seek greater alignment between disclosure and action.

Tagesson et al. (2009) [24] studied to explain the extent and content of social disclosure information on corporations' websites. Using empirical data based on annual financial statements and the websites and a multitheoretical framework, their findings suggested positive correlation of size and profitability with the content of social disclosure information on these websites. Furthermore they reported that State-owned corporations disclosed more social information on their websites than privately owned corporations. They also found significant differences between different industries regarding not only the extent of social disclosures, but also 
their content. Morhardt (2010) [25] used the Pacific Sustainability Index to analyse all material related to environmental and social performance on the corporate internet sites of 454 Fortune Global 500 and Fortune 1000 companies in 25 industrial sectors. It was found that the maximum scores for individual sectors were 20 75 percent of the total possible. Furthermore, it was reported that none of the variation in score was explained by corporate revenue in the Asian and European firms (revenues greater than about $\$ 9$ billion), however there was a very weak correlation between score and revenue for American firms of the size, and a stronger one when Fortune 1000 companies (all American) with revenues smaller than this were included. The study suggested that, as corporate size reaches a certain threshold, sustainability reporting becomes independent of it.

In relation to the banking sector, Branco and Rodrigues (2006) [6] attempted to ascertain whether Portuguese banks use their web sites as a medium to disclose social responsibility information. The findings suggested that banks with a higher visibility among consumers seem to exhibit greater concern to improve the corporate image through social responsibility information disclosure. Hinson et al. (2010) [15] in Ghana found that one of the banks that had won the most CSR awards at the Ghana banking awards had the poorest CSR communication content on its corporate website. They further noted that banks that had never won a CSR award previously seemed to have a better organised structure in respect of their CSR activities on their websites. Thus they posited that the findings clearly demonstrate the challenges that sometimes exist in transferring bricks-andmortar organisational capabilities to online environments.

\subsection{Hypothesis development}

Hinson et al. (2010) [15] opined that it is only natural to expect listed banks to be more visible than unlisted banks. Furthermore, Khan and Ali (2010) [26] posited that listed banks have greater commitment and exposure to investors to disclose than unlisted ones. Consequently according to Hinson et al. (2010) [15] listed banks expected to disclose more social responsibility information than unlisted banks. Besides, Domench (2003) cited in Hinson et al. (2010) [15] posited that although listed banks are not required to disclose their CSR activities any more extensively than their counterparts, listed banks receive more attention and are subject to extensive media coverage. Besides, Branco and Rodrigues (2006) [6] suggested that listed banks attribute greater importance to social responsibility disclosure as part of their legitimisation strategies when compared with unlisted banks in both media of disclosure. Thus following hypotheses were proposed:

$\mathbf{H}_{\mathbf{1}}$ : listing status of the banks influences the level of online CSR reporting.

$\mathbf{H}_{2}$ : listing status of the banks influences the level of CSR reporting in the annual reports.

\subsection{Data collection and analysis}

\section{Research Methodology}

The study sampled all the commercial banks that were operating in Malawi in 2012. Consistent with Tagesson et al. (2009) [24] the empirical data of the study was based on information provided in annual financial statements and corporate websites. Consistent further with Hinson et al. (2010) [15] the study involved locating the corporate websites of the banks and in case of unavailability of their links, popular search engines such as Google, and Yahoo! were used to locate the homepage of the banks. Banks qualifying for further analysis had to have an accessible web site and 2012 annual report for review consistent with Branco and Rodrigues (2006) [6]. The CSR data was collected from the websites and the annual reports of the commercial banks.

After collecting the relevant data on the banks' corporate websites, a scoring method was used in order to measure quantitatively the level of CSR posture of the sampled banks [15]. The scoring system involved assigning a point for each corporate social responsibility disclosure theme pertaining to any of the categories [6] based on the adopted framework. TABLE 1 presents the framework for CSR communication used in this study adopted from a similar study conducted in Ghana by Hinson et al. (2010) [15]. As can be noted on the framework the CSR are divided into internal and external disclosure. These are further subdivided into four namely; environmental disclosure, community involvement disclosure, human resource disclosure and products and customers disclosure.

The scoring was based on the dichotomous procedure. A score of " 1 " was awarded if an item was reported; otherwise a score of "0" was awarded [15]. Disclosure scores for each bank were added up and were not weighted, being assumed that each item of disclosure is equally important [6]; [20]. The study employed computation model adopted from Hossain and Reaz (2007) [18] which was as follows:

CSR score $=\sum_{j=1} \frac{d j}{n}$ 
Where: $d j=1$ if item $\mathrm{j}$ is disclosed; 0 if item $\mathrm{j}$ is not disclosed $\mathrm{n}=$ number of items.

\begin{tabular}{|c|c|c|}
\hline \multicolumn{3}{|c|}{ TABLE 1: Framework for bank CSR communication } \\
\hline & \multicolumn{2}{|c|}{$\begin{array}{ll}\text { INTERNAL DISCLOSURE } \\
\end{array}$} \\
\hline & HUMAN RESOURCES DISCLOSURE & PRODUCT \& CUSTOMER DISCLOSURE \\
\hline & 1. Employee health \& safety & 1. Product Quality \\
\hline & 2. Employee training & 2. Customer complaints/satisfaction \\
\hline \multirow{3}{*}{ CSR } & 3. Employee remuneration & 3. Provision for physically challenged customers \\
\hline & \multicolumn{2}{|c|}{ EXTERNAL DISCLOSURE } \\
\hline & ENVIRONMENTAL DISCLOSURE & COMMUNITY INVOLVEMENT DISCLOSURE \\
\hline & 1. Company's concern for environment & 1. Charitable donations and activities \\
\hline & 2. Lending and investment policies & 2. Support for education \\
\hline & 3. Conservation of energy in business & 3. Sport sponsoring or recreational projects \\
\hline
\end{tabular}

\subsection{Model specification}

The other aim of the study was to examine the influence of the listing status on the level of both the online CSR reporting and CSR reporting in the annual reports. Thus two models were formulated with the CSR scores as the dependent variable and listing status as the independent variable. The regression models used were as stated below:

Model I:

CSR Score (Online $)=\beta_{0}+\beta_{1}$ LISTING $+e$

Model II:

CSR score (Annual Reports) $=\alpha_{0}+\alpha_{1}$ LISTING $+e$

Where: CSR Score (Online) = total CSR score received for CSR disclosures on the website CSR score (Annual Reports) = total CSR score received for CSR disclosures in the annual report $\beta_{0}, \alpha_{0}=$ Coefficients of the Intercepts

LISTING $=$ Listings status

$\beta_{1,} \alpha_{1}=$ Coefficients of the dependent variable

$\mathrm{e}=$ the error term

\section{Results And Discussion}

This section presents the results of the study and the ensuing discussion. Consistent with Lepczynski (2003) [12], the results are based on information that was available in web sites of banks and their annual reports. Furthermore, using the adopted CSR score model the score range is 0 to 1 , where 0 is the lowest score and 1 is the maximum score.

\subsection{Levels of CSR reporting}

The search for the corporate websites for the banks revealed that out of the eleven (11) banks operating in Malawi, ten (10) have their own websites. One banks had its website suspended. The analysis further showed that out of the ten (10) websites, four (4) did not carry any CSR related information, this is exhibited by the zero (0.00) scores (see TABLE 2) and the remaining six had something in that regard. As can be further seen on TABLE 2 the highest online CSR score was 0.42 and the average score was 0.14 indicating very low overall level of online CSR reporting among the banks in Malawi.

Furthermore, analysis of the location of CSR information, revealed that out of the six websites with CSR related information, three (3) had a special corporate social responsibility section and the other three (3) made their CSR disclosures in form of corporate news. The study further revealed that the CSR disclosures were generally shallow, pictorial and unsystematic indicating that online CSR reporting by the banks in Malawi is still in infancy. This may suggest that there is a lack of awareness of the enormous benefits of CSR reporting using the Internet among the banks. As posited by Hinson et al. (2010) [15] the Internet is the window to the world for all banks operating in emerging market contexts and from an image management standpoint. Hinson et al. (2010) [15] therefore pointed out that a clear and structured discussion of CSR activities in corporate websites of the bank can go a long way of better endearing them to their present and future potential publics.

On the other hand, TABLE 2 indicates all the banks whose annual reports were accessible reported CSR information in them. The highest score was 0.67 and the lowest was 0.08 . The mean score was 0.40 , which is still low however relatively higher to online CSR score and CSR score of 0.3 reported by Lipunga (2013) 
[19]. As can be see, out of the 7 banks whose annual reports were available, 4 reported above average score which were also 0.5 of more and on the other hand, 3 had below average score. Analysis of the content of CSR information in annual reports also indicated that the disclosures were shallow, pictorial and unsystematic. The results indicate that the banks are aware of CSR reporting obligation and furthermore the reportage of majority of the banks is good, however there are the minority that poorly reporting thus pulling down the overall score.

\begin{tabular}{|l|c|c|}
\hline \multicolumn{3}{|c|}{ TABLE 2: Individual and Overall CSR Score of Banks } \\
\hline & $\begin{array}{c}\text { CSR Score } \\
\text { (Online) }\end{array}$ & $\begin{array}{c}\text { CSR Score (Annual } \\
\text { Reports) }\end{array}$ \\
\hline Bank A & 0.08 & 0.17 \\
\hline Bank B & 0.42 & 0.50 \\
\hline Bank C & 0.08 & 0.67 \\
\hline Bank D & 0.00 & 0.58 \\
\hline Bank E & 0.25 & Not available \\
\hline Bank F & 0.42 & 0.50 \\
\hline Bank G & 0.17 & 0.33 \\
\hline Bank H & 0.00 & 0.08 \\
\hline Bank I & 0.00 & Not available \\
\hline Bank J & 0.00 & Not available \\
\hline Total CSR Score (Mean) & $\mathbf{0 . 1 4}$ & $\mathbf{0 . 4 0}$ \\
\hline
\end{tabular}

On the other angle, TABLE 3 reveals that the CSR reporting by the banks was generally externally oriented. As can be seen on the TABLE 3, the online external CSR disclosure index was 0.25 while the internal score was 0.03 . On the other hand in annual reports the external score was 0.43 compare to the internal score of 0.38. It is observable that the internal and external scores for online reporting are far apart, besides being biased towards externally oriented CSR information. The results suggests that the online reporting by banks targets external stakeholders who are more interested in find out the contribution of the banks to the wider society than on the internal affairs of the banks. On the other hand, the internal and external scores of CSR reporting in the annual reports are closer and are both relatively higher compared to online scores. This suggests that CSR reporting in annual reports targets internal stakeholders who are essentially interested in the total and balanced view of the performance of the banks.

\begin{tabular}{|c|c|c|}
\hline \multicolumn{3}{|c|}{ TABLE 3: Interval Versus External Disclosures } \\
\hline & Online & $\begin{array}{l}\text { Annual } \\
\text { Reports }\end{array}$ \\
\hline \multicolumn{3}{|l|}{ Internal Disclosures } \\
\hline Human resource disclosures & 0.07 & 0.71 \\
\hline Product \& Customer Disclosures & 0.00 & 0.05 \\
\hline Internal Disclosures Score & 0.03 & 0.38 \\
\hline \multicolumn{3}{|l|}{ External Disclosures } \\
\hline Environmental Disclosures & 0.07 & 0.19 \\
\hline Community Involvement disclosures & 0.43 & 0.67 \\
\hline $\begin{array}{l}\text { External Disclosures Score } \\
\end{array}$ & 0.25 & 0.43 \\
\hline CSR Disclosure Score (Mean) & 0.14 & 0.40 \\
\hline
\end{tabular}

The low Online CSR reporting may be perhaps due to the fact that it is voluntary; in the same vein relatively higher CSR score in annual reports may be because it is mandatory in accordance with the Corporate Governance Guidelines issued by the Reserve Bank of Malawi. According to the guidelines Malawian banks are required to provide information of their corporate social responsibility and activities both negative and positive in their annual accounts [16]. The guidelines clearly stipulate that the "banks shall include in their annual report the nature and extent of their social activities, ethical, safety, health and environmental management policies and practices [16]. However, due to the lack of specific details within the guidelines in relation to the quantity and quality of the CSR information may be providing a leeway for superficial reporting hence the low overall CSR score. Therefore more needs to be done by the regulatory authorities perhaps by providing minimum guidelines in terms of both the quality and quantity of CSR reporting by the banks in Malawi in their annual reports. 
According to Wise and Ali (2009) [9] mandating of corporate social responsibility disclosure would provide better transparency of corporate activity which in turn will promote ethical business processes, which can have an important role to play in the mitigation of social obligations. Thus the regulatory authorities have the obligation to ensure that the banks are comply with what was intended in the guidelines and on the other hand, the banks are morally obliged to exceed the minimum for the general good. According to Hossain and Reaz (2007) [18], in order to maintain high quality disclosure and transparency as well as build up investors' and depositors' confidence, it is imperative for the banks to comply with the rules and regulations of the regulatory authorities and also to provide voluntary information.

\subsection{Results of the Paired test of the CSR Online reporting versus CSR reporting in annual reports}

Results of the paired test of CSR online reporting and CSR reporting in the annual reports are presented in TABLE 4 . The table displays a mean difference of 0.23714 between CSR score obtained from annual reports and the online CSR score. Since the p-value is less than 0.05, it can be concluded that there is statistically significant difference between levels of online CSR reporting and CSR reporting in annual reports. The results are contrary to the expectation the two should not be significantly different. The results may be suggestive that the higher CSR score in annual reports may be due to the fact that it is obligated by the regulations. Future studies should considered examining whether regulations influence the level of CSR disclosure, if confirmed the regulatory authorities may consider having explicit regulatory framework to enhance CSR reporting both in annual reports and online.

\begin{tabular}{|l|c|c|c|c|c|c|}
\hline \multicolumn{9}{|c|}{ TABLE 4: Paired Samples Test } & t & df & \multicolumn{1}{c|}{ Sig. } \\
\hline & 2-tailed) \\
\cline { 2 - 6 } & Mean & Std. Deviation & Std. Error Mean & & \\
\hline $\begin{array}{l}\text { CSR Index (Annual Reports) - CSR } \\
\text { Index (Online) }\end{array}$ & .23714 & .23935 & .09047 & 2.621 & 6 & .040 \\
\hline
\end{tabular}

\subsection{Listing status as determinant of CSR reporting}

TABLE 5 and TABLE 6 present the results of the regression analysis to determine whether the levels of CSR reporting are generally influenced by the listing status of the banks. As displayed in TABLE 5, the significance value is greater that than 0.05 for model I, suggesting that listing status have insignificant influence over Online CSR reporting.

\begin{tabular}{|c|c|c|c|c|c|c|c|c|}
\hline \multicolumn{9}{|c|}{ TABLE 5: Model Summary for Model I } \\
\hline \multirow[t]{2}{*}{$\mathbf{R}$} & \multirow[t]{2}{*}{ R Square } & \multirow{2}{*}{$\begin{array}{c}\text { Adjusted R } \\
\text { Square }\end{array}$} & \multirow{2}{*}{$\begin{array}{l}\text { Std. Error of } \\
\text { the Estimate }\end{array}$} & \multicolumn{5}{|c|}{ Change Statistics } \\
\hline & & & & R Square Change & F Change & df1 & df2 & $\begin{array}{c}\text { Sig. F } \\
\text { Change }\end{array}$ \\
\hline $.722^{\mathrm{a}}$ & .521 & .425 & .13809 & .521 & 5.433 & 1 & 5 & .067 \\
\hline
\end{tabular}

Furthermore, TABLE 6 shows that the significance value is greater than 0.05 for model II, thus suggesting that listing status does not significantly influence CSR reporting by banks in their annual reports.

\begin{tabular}{|c|c|c|c|c|c|c|c|c|}
\hline \multicolumn{9}{|c|}{ TABLE 6: Model Summary for Model II } \\
\hline \multirow[t]{2}{*}{$\mathbf{R}$} & \multirow{2}{*}{$\begin{array}{c}R \\
\text { Square }\end{array}$} & \multirow{2}{*}{$\begin{array}{l}\text { Adjusted R } \\
\text { Square }\end{array}$} & \multirow{2}{*}{$\begin{array}{l}\text { Std. Error of } \\
\text { the Estimate }\end{array}$} & \multicolumn{5}{|c|}{$\begin{array}{ll}\text { Change Statistics } \\
\end{array}$} \\
\hline & & & & R Square Change & F Change & df1 & df2 & $\begin{array}{l}\text { Sig. F } \\
\text { Change }\end{array}$ \\
\hline $.547^{\mathrm{a}}$ & .300 & .160 & .19993 & .300 & 2.139 & 1 & 5 & .203 \\
\hline
\end{tabular}

Based on the statistical evidence it can be concluded that the level of CSR reporting both online and in annual reports of the banks in Malawi is not influenced by the listing status. Knowing the importance of understanding the determinants of CSR reporting, the study recommends that future studies should consider evaluating the factors that influence CSR reporting by the Malawian banks.

\section{Conclusion}

According to CAMAC (2006) [4], disclosure of responsible business practices means that companies are accountable for the way they operate, how they manage corporate resources, and how they interact within the economy. It is recognised that disclosure of CSR activities by banks can be made in the form of publicising their efforts through numerous print and electronic media, such as newspapers, annual reports, and television among others [15]. The study was examining the levels of the CSR disclosures by the banks in Malawi through the internet and the annual reports. The results indicate generally low level of disclosures both on the internet 
and in the annual report. The results also found significant difference between them, with online CSR reporting having relatively lower level to CSR reporting in the annual report.

It must be noted that the low level of disclosure does not necessary mean less CSR activities by the banks, as stated by Penczar (2003) [1] banks are likely to be more involved, but they do not inform the public about it. Thus, promotion of CSR reporting among the banks is therefore needed in Malawi. There is more that the banks and the entire economy can benefit from CSR reporting using appropriate channels. As pointed out by Jurišová and Ďurková (2012) [10] effective communication of CSR activities can provides understanding and recognition of the value of the company, which in the final phase has an impact on corporate identity and subsequently on the corporate image. Enhanced image of our banking sector enhances also the image of the entire economy. Therefore more needs to be done by the banks and the regulatory authorities to encourage CSR reporting both online and in the annual reports. According to Wise and Ali (2009) [9] both the regulatory authorities and banks must realise that corporate governance does not only depends on managerial performance but also on the consideration of social responsibility, the socio-cultural-environmental dimension of business procedure, legal and ethical practices with a focus on customers and other stakeholders of an organization.

\section{References}

[1] M Penczar, Corporate Social Responsibility in the national sector of listed companies, in Reporting on Corporate Social Responsibility by Banks, Financial Institutions and Listed Companies in Poland, 2003, The Gdansk Institute for Market Economics N Subramaniam, K. Hodge and J. Ratnatunga, Corporate Responsibility Reports Assurance Trends and the Role of Management Accountants. JAMAR, Vol. 4( 2), 2006, 1-10

[3] F Yeshmin, Visualization of Corporate Social Responsibility Information of Commercial Bank in Bangladesh, World Journal of Social Sciences, Vol. 2(5), 2012, 114-127
CAMAC,
Discussion
Paper:
Corporate
Social http://www.camac.gov.au/camac/camac.nsf/byHeadline/PDFSubmissions_2/\$file/ABA_CSR.pdf.

Responsibility,

2006

[5] M. A. K. Masud, CSR practices of private commercial banks in Bangladesh, $2011 \mathrm{http} / / \mathrm{mpra} . u b . u n i-m u e n c h e n . d e / 35496 /$

[6] M. C. Branco and L. L. Rodrigues, Communication of corporate social responsibility by Portuguese banks: A legitimacy theory perspective, Corporate Communications: An International Journal, Vol. 11(3), 2006, 232-248

[7] D. O'Rourke, Opportunities and obstacles for corporate social responsibility reporting in developing countries, 2004 http://csreuasia.org/pdf/CSR-Reporting\%20developing\%20countries.pdf

[8] M. Arnold, Non-Financial Performance Metrics for Corporate Responsibility Reporting Revisited. Working paper, 2009 http://www.som.cranfield.ac.uk/som/dinamiccontent/media/Research/Research\%20Centres/Doughty\%20Centre\%20for\%20Corporate\%20Responsibility/1arnold.pdf.

[9] V. Wise and M. M. Ali, Corporate Governance and Corporate Social Responsibility in Bangladesh with special reference to Commercial Banks. AIUB Bus Econ Working Paper Series, No 2009-05, 2009 http://orp.aiub.edu/WorkingPaper/WorkingPaper.aspx?year=2009

[10] V. Jurišová and K. Ďurková, CSR communication and its impact on corporate image, Review of Applied Socio- Economic Research, Vol. 4, (2), 2012, 145-149

[11] D. Cormier, W Aerts, M. Ledoux and M. Magnan, Web-Based Disclosure About Value Creation Processes: A Monitoring Perspective, ABACUS, Vol. 46 (3), 2010, 320-347

[12] B. Lepczynski, Corporate Social Responsibility (CSR) in the Polish banking sector, in Reporting on Corporate Social Responsibility by Banks, Financial Institutions and Listed Companies in Poland, 2003, The Gdansk Institiute for Market Economics

[13] N. Guimarães-Costa and M. Pina e Cunha, The Atrium Effect of Website Openness on the Communication of Corporate Social Responsibility, Corporate Social Responsibility and Environmental Management, Vol. 15, 2008, 43-51

[14] L. S. O. Wanderley, R. Lucian, F. Farache and J. Milton de Sousa Filho, CSR Information Disclosure on the Web: A Context-Based Approach Analysing the Influence of Country of Origin and Industry Sector, Journal of Business Ethics, Vol. 82, 2008, 369-378

[15] R. Hinson, R. Boateng and N. Madichie, Corporate social responsibility activity reportage on bank websites in Ghana, International Journal of Bank Marketing Vol. 28 (7), 2010, 498-518

[16] Reserve Bank Malawi, Corporate $\quad$ Governance $\quad$ Guidelines, 2010 http://www.rbm.mw/documents/basu/Corporate\%20Governance\%20Guidelines.pdf

[17] S. M. Nor and M. Asutay, Re-Considering CSR and Sustainability Identity of Islamic Banks in Malaysia: An Empirical Analysis, Pro. 8th International Conference on Islamic Economics and Finance, 2011 http://conference.qfis.edu.qa/app/media/324

[18] M. Hossain and M. Reaz, The Determinants and Characteristics of Voluntary Disclosure by Indian Banking Companies, Corporate Social Responsibility and Environmental Management, Vol. 14, 2007, 274-288

[19] A. M. Lipunga, Corporate Social Responsibility Reporting by Commercial Banks in Annual Reports: Evidence from Malawi, International Journal of Business and Social Research, Vol. 3(9), 2013, 88-101

[20] R. Tandanu and D. H. Wibowo, Ranking Indonesian listed banks at Indonesia Stock Exchange (IDX) on their corporate social responsibility disclosures from 2004 to 2006, Journal of Applied Finance and Accounting, Vol. 1(1), 2008, 73-98

[21] E. Kousa, Web-Based Corporate Social Responsibility Reporting in Finnish Listed Companies, Degree thesis, 2011

[22] P. Cheung and W. Mak, The relation between corporate social responsibility disclosure and financial performance: Evidence from the commercial banking industry, Master's thesis, Simon Fraser University, 2010.

[23] M. Kurniawan and D. H. Wibowo, Analysis on accounting conservatism and CSR disclosures of Indonesian Banks listed on IDX from 2004 to 2007, Journal of Applied Finance and Accounting, Vol. 2(2), n.d, 13-30

[24] T. Tagesson, V. Blank, P. Broberg and S. Collin, What Explains the Extent and Content of Social and Environmental Disclosures on Corporate Websites: A Study of Social and Environmental Reporting in Swedish Listed Corporations, Corporate Social Responsibility and Environmental Management, Vol. 16, 2009, 352-364

[25] J. E. Morhardt, Corporate Social Responsibility and Sustainability Reporting on the Internet, Business Strategy and the Environment, Vol. 19, 2010, 436-452

[26] H. Khan and M. Ali, An empirical investigation and users' perceptions on intellectual capital reporting in banks: Evidence from Bangladesh, Journal of Human Resource Costing and Accounting, Vol. 14(1), 2010, 48-69. 